Grażyna B. Szczygiet

\title{
UCIECZKI SKAZANYCH Z ZAKŁADÓW KARNYCH. ZAGROŻENIE SPOŁECZNE CZY NATURALNY ELEMENT IZOLACJI?
}

Kara pozbawienia wolności, jak żadna inna z katalogu kar, ingeruje w wolność człowieka. Zważywszy, iż jest to najbardziej dolegliwa kara, do zakładów karnych trafią więc sprawcy czynów o znacznym bądź dużym stopniu społecznej szkodliwości, sprawcy, w stosunku do których sąd uznał, że celowa jest, na pewien czas, ich izolacja od społeczeństwa. W przypadku bowiem sprawców czynów o mniejszym stopniu społecznej szkodliwości sąd, zgodnie z zasadą ultima ratio, ma do dyspozycji kary wolnościowe, jak kara grzywny czy kara ograniczenia wolności, instytucje związane z poddaniem sprawcy próbie, a mianowicie warunkowe umorzenie postępowania czy warunkowe zawieszenie wykonania kary pozbawienia wolności.

Człowiek, jak trafnie zauważa T. Szymanowski ${ }^{1}$, jest , istotą stworzoną do wolności i jego uwięzienie, choćby usprawiedliwione, stwarza nie tylko dolegliwe, ale też nienaturalne warunki jego egzystencji” i rodzi marzenie, by jak najszybciej odzyskać utraconą wolność.

Odkąd więc powstały więzienia, ludzie w nich przebywający czynili wszystko by się z nich uwolnić. Nie będzie więc truizmem twierdzenie, że w całej historii więziennictwa i w czasach mam współczesnych nie znajdziemy na świecie więzienia, z którego nie uciekano, bądź nie podejmowano takich prób. Tytułem przykładu można wskazać na słynne więzienie Altacraz² , w którym od 1934 roku do 1963 roku odnotowano 36 prób ucieczek, z czego 23 uniemożliwiono, siedmiu zbiegów zastrzelono, jeden utoną̧, a pięciu zaginęło. W naszym kraju również miało miejsce szereg ucieczek z zakładów karnych czy aresztów śledczych. Można wskazać na spektakularną ucieczkę skazanego Zdzisława N. z aresztu śledczego. Skazany, będąc na spacerze wraz z innymi skazanymi, a pole spacerowe - co należy podkreślić - było nadzorowane przez funkcjonariuszy i ogrodzone siatką także z góry, nagle zboczył ze ścieżki na trawnik i zapadł się pod ziemię na oczach nadzorujących spa-

1 T. Szymanowski, Polityka karna i penitencjarna w Polsce w okresie przemian prawa karnego. Podstawowe problemy w świetle badań empirycznych, Warszawa 2004, s. 260.

2 S. Christianson, Więzienia świata. Spojrzenie na najsłynniejsze zakłady penitencjarne, Warszawa 2006, s. 135. 
cer funkcjonariuszy Służby Więziennej. Jak się okazało, zbiegł przez tunel zaczynający się na polu spacerowym, a kończący w warsztatach przylegającego do aresztu śledczego budynku, szkół budowlanych ${ }^{3}$. W sierpniu 2007 roku skazani przebywający w Areszcie Śledczym w Kozielsku ${ }^{4}$ wydostali się z celi przez dziurę w zewnętrznej ścianie budynku, wydłubując tunel o wymiarach 44 na $46 \mathrm{~cm}$ i głębokości $64 \mathrm{~cm}$. Wyjęto 28 cegieł. Budowa tunelu zajęła skazanym ponad miesiąc. Podobne zdarzenie miało miejsce w Zakładzie Karnym w Kamińsku w styczniu 2009 roku. Dwaj skazani wydrążyli w ścianie otwór o wymiarach 36 na $26 \mathrm{~cm}$. i przez tę dziurę próbowali uciec. Ucieczka zakończyła się obrażeniami w postaci złamania kończyn dolnych w wyniku upadku na twarde podłoże $e^{5}$ Zdarzają się i tak specyficzne ucieczki, jak z Zakładu Karnego w Wołowie w grudniu 2007 roku' ${ }^{6}$. Skazany na spadochronie, który wykonał z ręcznika, ,sfruną̧” z dachu budynku głównego na leżący 10 metrów poniżej dach zakładów naprawczych.

Jednym z zadań wykonywania kary pozbawienia wolności, jak wynika z kodeksu karnego wykonawczego (art. 73), jest ochrona społeczeństwa przed przestępczością. Ochrona społeczeństwa przed przestępcami przebywającymi w zakładach karnych to także zadanie Służby Więziennej

Rodzi się więc pytanie, czy pobyt skazanego w zakładzie karnym zapewnia społeczeństwu poczucie bezpieczeństwa, a więc że nie będzie ono narażone na dalszą działalność przestępczą z jego strony. Podejmując próbę udzielenia odpowiedzi na tak postawione pytanie, należy skoncentrować się na kilku problemach, które można sformułować w postaci następujących pytań:

- jaka jest skala zjawiska, jakim są ucieczki skazanych z jednostek penitencjarnych?

- w czym tkwi zagrożenie dla społeczeństwa?

- czy regulacje prawne przewidziane w kodeksie karnym wykonawczym, a dotyczące stopnia zabezpieczenia w poszczególnych typach zakładów karnych służą właściwej realizacji zadania, jakie ma do spełnienia służba więzienna, a mianowicie ochrony społeczeństwa przed przestępcami?

Przechodząc do analizy zakresu zjawiska, posłużę się wykresem.

Szerzej zob. Forum Penitencjarne 2007, nr 10, s. 16-17.

Zob. Forum Penitencjarne 2009, nr 4, s. 20-21.

Szerzej zob. Forum Penitencjarne 2007, nr 1, s. 16-17.

Zob. art. 1 pkt 4 ustawy z dnia 26 kwietnia 1996 r. o Służbie Więziennej - Dz.U. 1996, Nr 61, poz. 283 z późn. $\mathrm{zm}$. 
Wykres nr 1. Ucieczki dokonane - liczba osadzonych

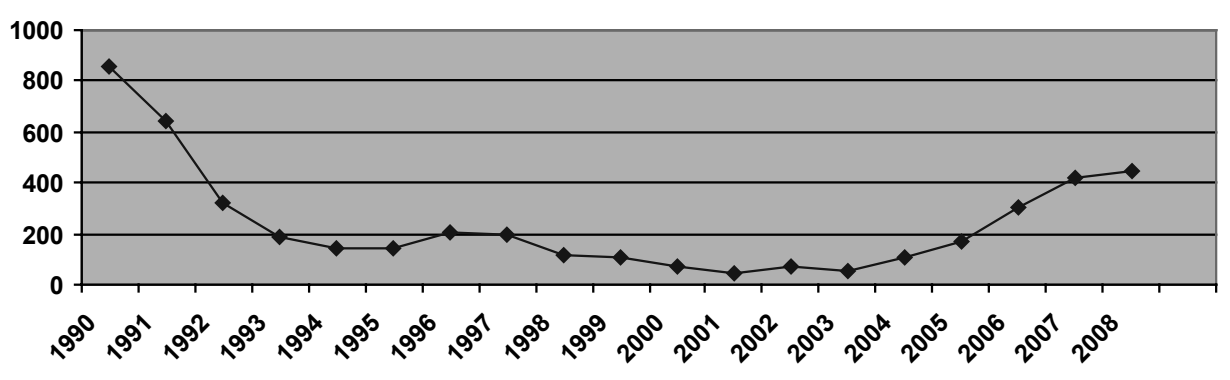

Źródto: dane CZSW

W ostatnich latach PRL liczba osadzonych, którzy dokonali ucieczek z jednostek penitencjarnych, wahała się pomiędzy 750 (1984 r.) a 933 (1989 r.) ${ }^{8}$. Od 1989 roku do 1995 roku liczba osadzonych, którzy dokonali ucieczek, zmniejszała się systematycznie i istotnie. Gdy w 1989 roku z jednostek penitencjarnych dokonało ucieczek 993 osadzonych, to w 1995 roku ta grupa zmniejszyła się do 143 osadzonych. Ta tendencja spadkowa utrzymywała się do 1995 roku. W 1996 roku nastąpił wręcz skokowy, w porównaniu do 1995 roku, wzrost liczby skazanych, którzy dokonali ucieczek z jednostek penitencjarnych, bowiem gdy w roku 1995 z jednostek penitencjarnych dokonało ucieczek 143 osadzonych, to 1996 roku uczyniło to aż 206 osób. Od roku 1997 systematycznie zmniejszała się liczba osadzonych, którzy dokonywali ucieczek z jednostek penitencjarnych. Ta tendencja utrzymywała się do roku 2001. W tym roku wystąpił najniższy wskaźnik ucieczek z jednostek penitencjarnych na przestrzeni lat 1990-2001. Z jednostek uciekły 42 osoby. Jednak już w następnym roku liczba ta wzrosła do 74, lecz w roku 2003 ponownie zmniejszyła się, ale do 51. Od 2004 roku obserwujemy systematyczny i dość znaczący wzrost liczby osadzonych dokonujących ucieczek z jednostek penitencjarnych. Gdy w 2004 roku ucieczek dokonało 105 osadzonych, to w 2008 roku uczyniło to 447 osób, a więc na przestrzeni czterech lat nastąpił prawie 4-krotny wzrost liczby osadzonych, którzy dokonali ucieczek.

Oceniając skalę zjawiska, należy spojrzeć przez pryzmat populacji osadzonych w jednostkach penitencjarnych. Za podstawę analizy oceny posłużą dane w tabeli poniżej. 
Grażyna B. Szczygieł

Tabela nr 1. Średnia liczba osadzonych i liczba osób, które dokonały ucieczek

\begin{tabular}{|c|c|c|c|c|c|}
\hline \multirow{2}{*}{ Rok } & \multicolumn{2}{|c|}{ osadzeni } & \multicolumn{3}{c|}{ osadzeni dokonujący ucieczek } \\
\cline { 2 - 6 } & ogółem & wskaźnik wzrostu & $\mathrm{lb}$ & $\%$ & wskaźnik wzrostu \\
\hline 1997 & 57705 & 100 & 179 & 0,31 & 100 \\
\hline 1998 & 58350 & 101 & 97 & 0,17 & 55 \\
\hline 1999 & 55436 & 96 & 111 & 0,20 & 62 \\
\hline 2000 & 64246 & 111 & 75 & 0,12 & 42 \\
\hline 2001 & 78716 & 136 & 42 & 0,05 & 24 \\
\hline 2002 & 81391 & 141 & 75 & 0,09 & 53 \\
\hline 2003 & 81321 & 141 & 51 & 0,06 & 28 \\
\hline 2004 & 80239 & 139 & 105 & 0,13 & 59 \\
\hline 2005 & 82761 & 143 & 169 & 0,20 & 94 \\
\hline 2006 & 87370 & 151 & 302 & 0,35 & 169 \\
\hline 2007 & 89995 & 156 & 420 & 0,47 & 235 \\
\hline 2008 & 85920 & 149 & 447 & 0,52 & 250 \\
\hline
\end{tabular}

Źródto: dane CZSW, obliczenia wtasne

Z przedstawionych danych wynika, że na przestrzeni lat 1997-2008 osadzeni, którzy dokonali ucieczek z jednostek penitencjarnych, stanowili 0,31\%-0,52\% ogółu osadzonych. Godzi się zauważyć, że systematycznemu wzrostowi liczby osadzonych w zakładach karnych i aresztach śledczych towarzyszył systematyczny wzrost liczby osadzanych, którzy dokonali ucieczek z jednostek penitencjarnych.

Patrząc na liczbę osób, które dokonywały ucieczek z zakładów karnych z perspektywy tak znacznej populacji osadzonych, nasuwa się wniosek, że właściwie ucieczki nie są istotnym zagrożeniem w katalogu współczesnych zagrożeń bezpieczeństwa obywateli.

Należy jednak spojrzeć na tę kwestię przez nieco inny pryzmat. Trudno nie podzielić poglądu9 , że więzień, który uciekł z jednostki penitencjarnej i ukrywa się, jest w sytuacji szczególnie kryminogennej, a tym samym zagraża bezpieczeństwu innych osób. Skazany chce pozostać jak najdłużej poza murami więzienia, a więc podejmuje działania w celu minimalizacji możliwości ujęcia go. Musi więc korzystać z pomocy innych osób aby uzyskać środki na utrzymanie, odzież i dokumenty.

9 J. de Michelis, Ucieczki osób pozbawionych wolności, (w:) Stan i węzłowe problemy polskiego więziennictwa. Część II, Biuletyn RPO, Warszawa 1997, s. 221. 
Pomoc może uzyskać od najbliższych bądź od kolegów czy uciec się do popełnienia przestępstwa. $Z$ badań ${ }^{10}$ wynika, że najczęściej popełnianymi przez skazanych podczas ucieczki przestępstwami były przestępstwa przeciwko mieniu. Jeżeli skazany nie uzyska pomocy dobrowolnie, może uciec się do wymuszania określonych zachowań w stosunku do najbliższych czy też innych osób, szczególnie by udaremnić powiadomienie organów ścigania o miejscu jego pobytu, a więc zmuszać inne osoby do zachowań, które wyczerpują znamiona czynów zabronionych.

Nie można pominąć jeszcze jednej kwestii, a mianowicie, kto dokonał ucieczki. Populacja osadzonych w zakładach karnych jest zróżnicowana. Są tam sprawcy czynów o różnym stopniu społecznej szkodliwości, a więc recydywiści skazani za kradzieże i sprawcy zabójstw, osoby biorące udział w zorganizowanych grupach przestępczych czy zabójcy na zlecenie. W płaszczyźnie zapewnienia ochrony społeczeństwu przed przestępcami szczególnie istotne są: rodzaj popełnionego przestępstwa i stan zdrowia psychicznego, a przede wszystkim stopień demoralizacji i zagrożenia społecznego skazanego. $Z$ całą pewnością większe zagrożenie dla bezpieczeństwa społecznego niesie ucieczka z zakładu karnego sprawców poważnych przestępstw czy działających w zorganizowanych grupach lub związkach przestępczych niż sprawców drobnych kradzieży.

Dostrzegając zróżnicowanie populacji skazanych i ich stopień demoralizacji i zagrożenia społecznego, ustawodawca uznał za celowe zróżnicowanie zakładów karnych, w których odbywają oni karę. Zróżnicowanie zakładów karnych pozwala na właściwe rozmieszczenie skazanych i zminimalizowanie zagrożenia społecznego. W kodeksie karnym wykonawczym (art. $70 § 1$ ) przewidziano trzy typy zakładów karnych, a mianowicie: typu zamkniętego, półotwartego i otwartego. Zakłady te różnią się stopniem zabezpieczenia, izolacji skazanych oraz wynikającymi z tego ich obowiązkami i uprawnieniami w zakresie poruszania się w zakładzie i poza jego obrębem.

W zakładzie karnym typu zamkniętego odbywają kary skazani na najsurowsze kary, a mianowicie karę dożywotniego pozbawienia wolności i karę 25 lat pozbawienia wolności, skazani przeniesieni z zakładu karnego typu półotwartego lub otwartego, gdy ich postawa i zachowanie uzasadniają potrzebę wykonywania kary w warunkach zwiększonej izolacji i zabezpieczenia oraz inni skazani ze względu na zagrożenie społeczne albo zagrożenie dla bezpieczeństwa zakładu.

W zakładach karnych typu zamkniętego stosuje się pełny system ochrony ${ }^{11}$ w celu niedopuszczenia do wypadków nadzwyczajnych, a w szczególności ucieczki

\footnotetext{
10 W. Dadak, Niektóre sytuacyjne i podmiotowe uwarunkowania ucieczek skazanych odbywających karę pozbawienia wolności, Przegląd Więziennictwa Polskiego 1995, nr 9, s. 35.

11 Rozporządzenie Ministra Sprawiedliwości z dnia 31 października 2003 roku w sprawie sposobów ochrony jednostek organizacyjnych Służby Więziennej, Dz.U. Nr 194, poz. 1902 z późn. zm.
} 
skazanego. Ochrona zewnętrzna wykonywana jest wzdłuż linii ogrodzenia ochronnego, składającego się z linii zewnętrznej wykonanej z materiału pełnego oraz linii wewnętrznej, a także usytuowanego między nimi pasa ochronnego. W ochronie zewnętrznej mogą być wyznaczone posterunki zbrojne. Okna budynków, w których stale i czasowo przebywają skazani, wyposażone są w kraty lub spełniające ich funkcję inne zabezpieczenia techniczno-ochronne. Drzwi i kraty wejściowe do budynków i oddziałów mieszkalnych oraz wejścia do budowli i przejścia na terenie jednostki otwierane są tylko na czas niezbędny. Zgodnie z art. $90 \mathrm{kkw}$ cele mieszkalne mogą być otwarte w porze dziennej tylko przez określony czas i to jeżeli względy bezpieczeństwa nie stoją temu na przeszkodzie. Ruch skazanych po terenie jednostki odbywa się w sposób zorganizowany i pod dozorem. Zajęcia kulturalno-oświatowe i sportowe oraz nauczanie organizuje się w obrębie zakładu karnego. Skazani odbywający karę w tego typu zakładzie mogą być zatrudniani poza terenem zakładu karnego tylko w pełnym systemie konwojowania. W tym systemie konwojowania rejon zatrudnienia zabezpiecza się ogrodzeniem ochronnym, w linii ogrodzenia ochronnego wyznacza się posterunki zbrojne, wewnątrz rejonu zatrudnienia wyznacza się posterunek uzbrojony.

Należy zaznaczyć, że system zabezpieczeń przewidziany w zakładzie karnym typu zamkniętego obowiązuje również w areszcie śledczym.

Ustawodawca uznał, że pewna grupa skazanych, mimo że została zakwalifikowana do odbywania kary w zakładzie karnym typu zamkniętego, powinna przebywać w warunkach zapewniających wzmożoną ochronę społeczeństwa i bezpieczeństwo zakładu karnego (art. $88 \mathrm{kkw}$.). Cele mieszkalne oraz miejsca i pomieszczenia przeznaczone do pracy, nauki, przeprowadzania spacerów, widzeń, odprawiania nabożeństw, spotkań religijnych oraz zajęć kulturalno-oświatowych, z zakresu kultury fizycznej i sportu wyposaża się w wewnętrzne kraty zainstalowane za drzwiami wejściowymi i przed otworami okiennymi, siatki, a w miarę potrzeb również w przesłony na zewnątrz otworów okiennych, w kraty okienne ze stali o podwyższonej wytrzymałości na przecinanie lub wyposaża się w zabezpieczenia elektroniczne, a także zabezpieczenia uniemożliwiające samowolne opuszczenie tych pomieszczeń przez skazanego. Pomieszczenia te można wyposażyć w urządzenia umożliwiające monitoring, zaś cele można dodatkowo wyposażyć w kamery telewizyjne i urządzenia umożliwiające nasłuch. Cele mieszkalne pozostają zamknięte całą dobę i są częściej kontrolowane niż cele innych skazanych. Skazani mogą uczyć się i pracować, bezpośrednio uczestniczyć w nabożeństwach, spotkaniach religijnych i nauce religii oraz korzystać z różnych form aktywności, a mianowicie z zajęć kulturalnooświatowych, sportowych w oddziale, w którym są osadzeni. Poruszanie się skazanych po terenie zakładu odbywa się pod wzmocnionym dozorem i jest ograniczone do niezbędnych potrzeb. Skazanych poddaje się kontroli osobistej przy każdorazowym wyjściu i powrocie do celi. Skazani ci nie mogą korzystać z własnej odzieży 
i obuwia. Spacery odbywają się w wyznaczonym miejscu pod wzmocnionym dozorem. Plac spacerowy zabezpiecza się w sposób uniemożliwiający samowolne jego opuszczenie przez osadzonego. W tym celu stosuje się przykrycie placu siatką, prętami lub drutem. Miejsce spaceru może być wyposażone w urządzenia umożliwiające monitoring. Skazany, poza celą mieszkalną i pomieszczeniami przeznaczonymi do pracy, nauki, widzeń, czynności procesowych, odprawiania nabożeństw, spotkań religijnych i nauczania religii oraz zajęć kulturalno-oświatowych z zakresu kultury fizycznej i sportu, pozostaje pod stałym i bezpośrednim dozorem co najmniej dwóch funkcjonariuszy. W czasie wykonywania obowiązków z tymi skazanymi oddziałowy i funkcjonariusz z nim współpracujący pełnią służbę w kamizelkach ochronnych i wyposażeni są w osobiste sygnalizatory alarmowe oraz środki przymusu bezpośredniego.

W takich warunkach osadza się skazanego, którego właściwości, warunki osobiste, sposób zachowania się przy popełnieniu przestępstwa, rodzaj i rozmiar ujemnych następstw przestępstwa, sposób zachowania się w trakcie pobytu w zakładzie karnym lub stopień demoralizacji stwarzają poważne zagrożenie społeczne albo poważne zagrożenie dla bezpieczeństwa zakładu karnego i który popełnił przestępstwo w szczególności: zamachu na niepodległość lub integralność Rzeczypospolitej Polskiej, konstytucyjny ustrój państwa lub konstytucyjne organy Rzeczypospolitej Polskiej, życie Prezydenta Rzeczypospolitej Polskiej, jednostkę sił zbrojnych Rzeczypospolitej Polskiej, przestępstwo ze szczególnym okrucieństwem, przestępstwo wzięcia lub przetrzymywania zakładnika albo w związku z wzięciem zakładnika, przestępstwo uprowadzenia statku wodnego lub powietrznego, przestępstwo z użyciem broni palnej, materiałów wybuchowych albo łatwo palnych, oraz który podczas uprzedniego lub obecnego pozbawienia wolności stwarzał zagrożenie dla bezpieczeństwa zakładu karnego lub aresztu śledczego w ten sposób, że był organizatorem lub aktywnym uczestnikiem zbiorowego wystąpienia w zakładzie karnym lub areszcie śledczym, dopuścił się czynnej napaści na funkcjonariusza publicznego lub inną osobę zatrudnioną w zakładzie karnym lub areszcie śledczym, był sprawcą zgwałcenia albo znęcał się nad skazanym lub tymczasowo aresztowanym, uwolnił się albo usiłował uwolnić się z zakładu karnego typu zamkniętego lub aresztu śledczego, albo podczas konwojowania poza teren takiego zakładu lub aresztu śledczego.

W zakładzie karnym typu półotwartego odbywają karę przede wszystkim skazani, którzy wybrali system programowanego oddziaływania, a więc ci, którzy wyrazili chęć korzystania z oferty pomocy administracji zakładu karnego w zmianie postaw. W tego typu zakładzie odbywają karę także skazani za przestępstwa nieumyślne oraz skazani, którzy zostali przeniesieni z zakładu karnego typu zamkniętego ze względu na postawę i zachowanie. 
W zakładzie karnym typu półotwartego obowiązuje ograniczony system ochrony. W ochronie zewnętrznej mogą być wyznaczone posterunki uzbrojone wyposażone w broń palną, z której miotane są pociski niepenetracyjne. Okna budynków mogą być wyposażone w zabezpieczenia techniczno-ochronne, drzwi i kraty wejściowe do budynków i oddziałów mieszkalnych otwierane są tylko na pewien czas. Dyrektor może podjąć decyzję o otwarciu w okresie od zakończenia apelu porannego do rozpoczęcia apelu wieczornego drzwi, krat, wejść i przejść, określając czas ich otwarcia. Zgodnie z art. $91 \mathrm{kkw}$. cele mieszkalne skazanych pozostają otwarte w porze dziennej, natomiast w porze nocnej mogą być zamknięte. Skazani mogą być zatrudniani poza terenem zakładu karnego w systemie zmniejszonego konwojowania. W zmniejszonym systemie konwojowania konwojenta można wyposażyć w broń palną, grupa robocza może być podzielona na podgrupy. Skazani ci mogą być zatrudnieni także na pojedynczych stanowiskach pracy. Mogą uzyskać zezwolenie na uczestniczenie w nauczaniu, szkoleniu oraz zajęciach terapeutycznych organizowanych poza terenem zakładu karnego, a także brać udział w organizowanych przez administrację poza terenem zakładu karnego zajęciach kulturalno-oświatowych i sportowych.

W zakładzie karnym typu otwartego, w którym odbywają karę skazani przeniesieni z zakładu typu zamkniętego bądź półotwartego, gdy ich postawa i zachowanie przemawiają za umieszczeniem w warunkach zakładu typu otwartego, stosuje się uproszczony system ochrony. W ochronie zewnętrznej nie wyznacza się posterunków uzbrojonych, okna budynków mogą być wyposażone w zabezpieczenia techniczno-ochronne, budynek i oddziały mieszkalne pozostają zamknięte w okresie od rozpoczęcia apelu wieczornego do zakończenia apelu porannego, a otwarte w okresie od zakończenia apelu porannego do rozpoczęcia apelu wieczornego. Dyrektor może podjąć decyzję o otwarciu oddziału w okresie od zakończenia apelu wieczornego do rozpoczęcia apelu porannego. Zgodnie z art. $92 \mathrm{kkw}$. skazani mogą poruszać się po terenie zakładu w czasie i w miejscach ustalonych w wewnętrznym porządku. Skazani są zatrudniani przede wszystkim poza terenem zakładu karnego, mogą uzyskać zezwolenie na uczestnictwo w nauczaniu, szkoleniu oraz zajęciach terapeutycznych oraz w organizowanych przez administrację grupowych zajęciach kulturalno-oświatowych i sportowych poza terenem zakładu karnego.

Należy podzielić pogląd J. de Michelis ${ }^{12}$, iż „,w zakładach karnych typu półotwartego i otwartego dominującym czynnikiem zapobiegania ucieczkom jest czynnik psychologiczny. Opiera się on głównie na zaufaniu okazywanym skazanym oraz wierze w ich poczucie odpowiedzialności i samodyscyplinę".

12 J. de Michelis, Ucieczki osób pozbawionych wolności w: Stan i węzłowe problemy polskiego więziennictwa. Część II, Biuletyn RPO, Warszawa 1997, s. 225 
Godzi się zauważyć, iż z ustawy o Służbie Więziennej (art. 19 pkt 2) wynika, że funkcjonariusze Służby Więziennej mogą stosować wobec osadzonych, jeżeli jest to konieczne w celu przeciwdziałania ucieczce, środki przymusu bezpośredniego, a mianowicie: siłę fizyczną, umieszczenie w celi zabezpieczającej, założenie kasku ochronnego, kajdany lub prowadnice, pasy obezwładniające, siatkę obezwładniającą, chemiczne środki obezwładniające, reflektor olśniewający, petardy, pałki służbowe, pociski niepenetrujace miotane $\mathrm{z}$ broni palnej. Mają prawo także do użycia broni palnej lub psa służbowego, ale tylko w celu udaremnienia ucieczki z zakładu zamkniętego lub aresztu śledczego.

Wszystkich skazanych poddaje się kontroli osobistej lub pobieżnej przed opuszczeniem oddziału mieszkalnego lub miejsca zatrudnienia i po powrocie do nich, przed indywidualnymi rozmowami lub spotkaniami odbywającymi się w oddziale mieszkalnym z przedstawicielami administracji lub innych podmiotów oraz bezpośrednio przed rozpoczęciem konwojowania.

Przechodząc do oceny skuteczności systemu zabezpieczeń, jako wyznacznik przyjmę liczbę skazanych dokonujących ucieczek.

Tabela nr 2. Ucieczki z jednostek penitencjarnych - liczba skazanych

\begin{tabular}{|c|c|c|c|c|c|c|c|}
\hline \multirow{2}{*}{ Rok } & \multirow{2}{*}{$\begin{array}{c}\text { Skazani dokonujący } \\
\text { ucieczek }\end{array}$} & \multicolumn{2}{|c|}{$\mathrm{z}$ terenu jednostki } & \multicolumn{2}{|c|}{ z zatrudnienia } & \multicolumn{2}{|c|}{ spod konwoju } \\
\cline { 3 - 8 } & $\mathrm{lb}$ & $\%$ & $\mathrm{lb}$ & $\%$ & $\mathrm{lb}$ & $\%$ \\
\hline 1997 & 179 & 31 & 17,32 & 137 & 76,54 & 11 & 6,14 \\
\hline 1998 & 97 & 27 & 27,83 & 64 & 65,98 & 6 & 6,19 \\
\hline 1999 & 111 & 21 & 18,92 & 71 & 63,96 & 18 & 16,22 \\
\hline 2000 & 75 & 26 & 34,67 & 41 & 54,67 & 8 & 10,66 \\
\hline 2001 & 42 & 9 & 21,43 & 32 & 76,19 & 1 & 2,38 \\
\hline 2002 & 75 & 9 & 12,00 & 63 & 84,00 & 3 & 4,00 \\
\hline 2003 & 51 & 7 & 13,73 & 41 & 80,39 & 3 & 5,88 \\
\hline 2004 & 105 & 15 & 14,29 & 90 & 85,71 & 0 & 0 \\
\hline 2005 & 169 & 11 & 6,5 & 154 & 91,12 & 4 & 2,37 \\
\hline 2006 & 302 & 10 & 3,31 & 288 & 95,36 & 4 & 1,33 \\
\hline 2007 & 420 & 7 & 1,67 & 410 & 97,62 & 3 & 0,71 \\
\hline 2008 & 447 & 9 & 2,01 & 438 & 97,99 & 0 & 0 \\
\hline
\end{tabular}

Źródto: dane CZSW, obliczenia własne 
W warunkach jednostki penitencjarnej można wskazać na trzy miejsce, z których osadzeni mogą dokonać ucieczki, a mianowicie: $\mathrm{z}$ terenu jednostki, terenu zatrudnienia i spod konwoju. Uwzględniając miejsce dokonania ucieczki, należy stwierdzić, że najwięcej osób dokonuje ucieczek z miejsca zatrudnienia. Udział tych osób w populacji osadzonych, którzy dokonali ucieczki w latach 1997-2008, wahał się w granicach 54,67\%-97,99\%.

Należy zauważyć, iż od 2000 r. następuje systematyczny wzrost skazanych, którzy dokonali ucieczek z miejsca zatrudnienia. W 2008 roku - w porównaniu do roku 2000 - nastąpił ponad dziesięciokrotny wzrost liczby skazanych, którzy dokonali ucieczki z miejsca zatrudnienia. Nietrudno wskazać na przyczynę. Od 2000 roku obserwuje się wzrost, a w ostatnich latach nawet dość istotny, liczby skazanych którzy pracują i wykonują pracę poza terenem zakładu karnego.

W analizowanym okresie istotnie zmniejszyła się liczba skazanych, którzy dokonali ucieczek z terenu jednostki czy spod konwoju. O ile w latach 2000-2004 skazani, którzy dokonali ucieczki z terenu jednostki, stanowili 34,67\%-12,00\% ogółu osadzonych, którzy dokonali ucieczki, to w latach 2005-2008 udział ten wahał się w granicach 6,5\%-1,67\%. Także istotnie zmniejszyła się w analizowanym okresie liczba skazanych, którzy dokonali ucieczki spod konwoju Służby Więziennej. Godzi się zauważyć, iż skazani częściej dokonują ucieczek spod konwoju Policji niż spod konwoju Służby Więziennej. Liczba osadzonych, którzy dokonali ucieczek spod konwoju Policji, w latach 2000-2008, zamykała się w granicach 9-27. Może to świadczyć o tym, iż Służba Więzienna jest lepiej przygotowana do wykonywania tego zadania.

Przejdźmy następnie do analizy ucieczek z terenu jednostki penitencjarnej, a mianowicie z aresztu śledczego i zakładu karnego.

Tabela nr 3. Ucieczki z terenu jednostki penitencjarnej - liczba osadzonych

\begin{tabular}{|c|c|c|c|c|c|c|c|c|}
\hline \multirow{2}{*}{ Rok } & \multirow{2}{*}{ Ogółem } & \multicolumn{2}{|c|}{ areszt śledczy } & \multicolumn{2}{|c|}{ zakład karny } & \multicolumn{3}{|c|}{ zakład karny typu } \\
\cline { 2 - 9 } & $\mathrm{lb}$ & $\%$ & $\mathrm{lb}$ & $\%$ & zamkniętego & półotwartego & otwartego \\
\hline 1999 & 21 & 2 & 9,52 & 19 & 90,48 & 0 & 18 & 1 \\
\hline 2000 & 26 & 0 & 0 & 26 & 100,00 & 3 & 20 & 3 \\
\hline 2001 & 9 & 2 & 22,22 & 7 & 77,78 & 0 & 5 & 2 \\
\hline 2001 & 8 & 1 & 12,5 & 7 & 87,50 & 0 & 1 & 6 \\
\hline 2003 & 11 & 1 & 9,09 & 10 & 90,91 & 0 & 8 & 2 \\
\hline 2004 & 15 & 0 & & 15 & 100,00 & 0 & 12 & 3 \\
\hline 2005 & 11 & 1 & 9,09 & 10 & 90,01 & 0 & 8 & 2 \\
\hline
\end{tabular}


Ucieczki skazanych z zakładów karnych zagrożenie społeczne...

\begin{tabular}{||c|c|c|c|c|c|c|c|c||}
\hline 2006 & 10 & 3 & 30,00 & 7 & 70,00 & 0 & 5 & 2 \\
\hline 2007 & 7 & 2 & 28,57 & 5 & 71,43 & 0 & 3 & 2 \\
\hline 2008 & 9 & 0 & 0 & 9 & 100,00 & 0 & 3 & 6 \\
\hline
\end{tabular}

Źródto: dane CZSW, obliczenia własne

Należy zauważyć, że jeżeli porównamy dwie jednostki, a mianowicie areszt śledczy i zakład karny, to jednoznacznie wynika, iż w analizowanym okresie sporadycznie zdarzały się ucieczki z aresztu śledczego. Jeżeli chodzi o ucieczki z zakładów karnych, to w zasadzie nie dokonywano ucieczek z zakładów karnych typu zamkniętego. W analizowanym okresie tylko w 2000 roku odnotowano dokonanie ucieczek przez trzech skazanych. $Z$ całą pewnością świadczy to o tym, iż wyżej scharakteryzowane zabezpieczenia są skuteczne.

Najczęściej dokonywano ucieczek z zakładu karnego typu półotwartego. Tylko w dwóch latach analizowanego okresu, a mianowicie w 2001 r. i 2008 roku, więcej skazanych uciekło z zakładu karnego typu otwartego.

Tabela nr 4. Ucieczki z zatrudnienia zewnętrznego - liczba osadzonych

\begin{tabular}{|c|c|c|c|c|c|c|}
\hline \multirow{3}{*}{ Rok } & \multirow{3}{*}{$\begin{array}{c}\text { Ucieczki z miejsca } \\
\text { zatrudnienia zewnętrznego }\end{array}$} & \multicolumn{3}{|c|}{ System konwojowania } & \multirow{2}{*}{\multicolumn{2}{|c|}{ Bez konwoju }} \\
\hline & & \multirow[t]{2}{*}{ pełny } & \multicolumn{2}{|c|}{ zmniejszony } & & \\
\hline & & & $\mathrm{lb}$ & $\%$ & $\mathrm{lb}$ & $\%$ \\
\hline 1997 & 137 & 0 & 55 & 40,15 & 82 & 59,85 \\
\hline 1998 & 64 & 0 & 15 & 23,44 & 49 & 76,56 \\
\hline 1999 & 71 & 0 & 24 & 33,80 & 47 & 66,20 \\
\hline 2000 & 41 & 0 & 16 & 39,02 & 25 & 60,98 \\
\hline 2001 & 32 & 0 & 8 & 0,03 & 24 & 99,97 \\
\hline 2002 & 63 & 0 & 5 & 7,94 & 58 & 92,06 \\
\hline 2003 & 41 & 0 & 4 & 9,76 & 37 & 90,24 \\
\hline 2004 & 90 & 0 & 9 & 10,00 & 81 & 90,00 \\
\hline 2005 & 154 & 0 & 10 & 6,49 & 144 & 93,51 \\
\hline 2006 & 288 & 0 & 9 & 3,13 & 279 & 96,87 \\
\hline 2007 & 410 & 0 & 6 & 1,46 & 402 & 98,54 \\
\hline 2008 & 438 & 0 & 0 & 0 & 438 & 100,00 \\
\hline
\end{tabular}

Źródto: dane CZSW, obliczenia wtasne 
W przypadku ucieczek z miejsca zatrudnienia, to najczęściej, jak wynika z przedstawionych danych, dokonywali ich skazani, którzy byli zatrudnienia bez konwoju.

Z przedstawionych danych jednoznacznie wynika, że wprowadzony system ochrony w pełni się sprawdza.

Oceniając system zabezpieczeń, nie można pominąć opinii funkcjonariuszy Służby Więziennej, a więc tych, którzy mają chronić społeczeństwo przed sprawcami przestępstw osadzonymi w jednostkach penitencjarnych.

Z badań ${ }^{13}$, którymi objęto 210 wychowawców i 495 oddziałowych, wynika, że funkcjonariusze pozytywnie oceniają system zabezpieczeń. Większość badanych, a mianowicie 191 (90,95\%) wychowawców i 465 (92,12\%) oddziałowych, oceniło, że wyposażenie cel w zabezpieczenia techniczno-ochronne jest zgodne z rozporządzeniem w sprawie sposobów ochrony, obrony i zapewnienia bezpieczeństwa zakładu karnego i aresztu śledczego. Tylko nieco mniej liczna grupa badanych, bowiem $180(85,7 \%)$ wychowawców i 424 (85\%) oddziałowych, oceniło, że wyposażenie miejsc, w których przebywają skazani, jest wystarczające dla zapewnienia bezpieczeństwa w zakładzie karnym i zapobieżeniu ucieczkom. Należy zaznaczyć, że te oceny dotyczą zakładów karnych typu zamkniętego.

Marzenie o wolności rodzi potrzebę wydostania się poza mury więzienia. Z badań ${ }^{14}$ wynika, że nie jest to jedyny powód ucieczek z jednostek penitencjarnych. Przyczyną ucieczek z zakładów karnych często jest pragnienie rozwiązania istotnych dla skazanego problemów powstających poza murami zakładów karnych. Takim problemem, na który wskazują skazani, jest - szczególnie w przypadku skazanych, którzy mieli silne więzi z rodziną przed osadzeniem w zakładzie karnym - zerwanie kontaktów przez najbliższych, informacja od osoby ,życzliwej”, że żona układa sobie nowe życie. Skazani wskazywali także na chęć załatwienia innych niż rodzinne spraw, a mających swoje źródło w aktywności skazanego sprzed rozpoczęcia odbywania kary pozbawienia wolności lub będących reakcją na zdarzenia, które według skazanych będą miały dla nich istotne znaczenie po zakończeniu kary, np. kwestie związane z pracą, mieszkaniem bądź zapobieżenie niekorzystnym zmianom sytuacji majątkowej. Wskazywano także na konflikty z innymi skazanymi, złe traktowanie przez funkcjonariuszy, przekonanie, że skazanie było nieuzasadnione lub

Badania prowadzono w latach 2003-2006 w ramach projektu badawczego zamawianego (nr PBZ-MIN-004/ T00/2002) „Rozwiązania prawne i organizacyjno-techniczne w zwalczaniu przestępczości zorganizowanej oraz terroryzmu ze szczególnym uwzględnieniem problematyki dowodów procesowych oraz instytucji świadka koronnego”. Autorka była kierownikiem zadania „Badania skazanych osadzonych w zakładach karnych uczestniczących w zorganizowanych grupach przestępczych”.

14 W. Dadak, Niektóre sytuacyjne i podmiotowe uwarunkowania ucieczek skazanych odbywajacych karę pozbawienia wolności, Przegląd Więziennictwa Polskiego 1995, nr 9, s. 22. Zob. także J. de Michelis, Ucieczki osób pozbawionych wolności, (w:) Stan i węzłowe problemy polskiego więziennictwa. Część II, Biuletyn RPO, Warszawa 1997, s. 236. 
orzeczona kara zbyt surowa. Często ucieczki są podyktowane chęcią udowodnienia, zwłaszcza gdy skazany należy do podkultury, odwagi.

Patrząc na wskazywane przez skazanych przyczyny ucieczek, nasuwa się spostrzeżenie, że kontakt skazanego ze światem poza murami więzienia, a szczególnie kontakt poza tymi murami może wpłynąć na rozładowanie wielu sytuacji stresowych, uregulowanie problemów i tym samym zminimalizować pragnienie ucieczki z zakładu karnego. Od wielu lat dostrzega się potrzebę kontaktów skazanego ze środowiskiem poza murami zakładu karnego, zwłaszcza że każdy skazany po pewnym czasie opuści mury więzienia. Takie kontakty umożliwiają zezwolenia na czasowe opuszczenie zakładu karnego.

W kodeksie karnym wykonawczym mamy rozbudowany system takich zezwoleń. Należy wskazać na:

- nagrodę w formie zezwolenia na widzenie bez dozoru poza obrębem zakładu karnego z osobą najbliższą lub godną zaufania na okres nie przekraczający jednorazowo 30 godzin (art. $138 \S 1$ pkt 7),

- nagrodę w formie zezwolenia na opuszczenie zakładu karnego bez dozoru na okres nie przekraczający jednorazowo 14 dni (art. $138 \S 1$ pkt 8),

- przepustkę w zakładzie karnym typu półotwartego, którą skazany może uzyskać nie częściej niż raz na dwa miesiące, łącznie na okres nie przekraczający 14 dni w roku (art. 91 pkt 7 kkw.),

- przepustkę w zakładzie typu otwartego, którą skazany może uzyskać nie częściej niż raz na miesiąc, na okres nie przekraczający 28 dni w roku (art. 92 pkt 9 kkw.),

- zezwolenia na opuszczenie zakładu karnego na czas nie przekraczający 5 dni (art. 141a $§ 1$ kkw.),

- zezwolenie na opuszczenie zakładu karnego łącznie na czas do 14 dni, zwłaszcza w celu podejmowania starań o uzyskanie po zwolnieniu odpowiednich możliwości zamieszkania i pracy (art. $165 \S 2 \mathrm{kkw}$.).

W przypadku tych instytucji szczególnie istotna jest właściwa ocena, czy skazany może opuścić zakład karny i nie będzie stanowić zagrożenia dla społeczeństwa. Wyznacznikiem trafności decyzji funkcjonariuszy Służby Więziennej mogą być wskaźniki niepowrotów z przepustek do zakładów karnych. 
Grażyna B. Szczygieł

Tabela $\mathrm{nr}$ 5. Udzielone przepustki i zezwolenia na czasowe opuszczenie zakładu karnego, aresztu śledczego w okresie od 1.01. do 31.12.2008 r.

\begin{tabular}{|l|c|c|c|c|}
\hline \multirow{2}{*}{ Przepustki i zwolnienia } & \multirow{2}{*}{$\begin{array}{c}\text { Liczba osób } \\
\text { korzystających }\end{array}$} & $\begin{array}{c}\text { Liczba } \\
\text { przepustek } \\
\text { i zezwoleń }\end{array}$ & lb & $\%$ \\
\cline { 5 - 5 } & 57633 & 117487 & 339 & 0,59 \\
\hline Ogółem & 3961 & 4429 & 15 & 0,38 \\
\hline Art. 91 pkt 7 & 4834 & 7531 & 23 & 0,47 \\
\hline Art. 92 pkt 9 & 22733 & 63366 & 93 & 0,41 \\
\hline Art. 138 §1 pkt 7 & 18508 & 32800 & 98 & 0,53 \\
\hline Art. 138 § pkt 8 & 6049 & 7560 & 102 & 1,69 \\
\hline Art. 141a §1 (bez asysty) & 879 & 908 & 1 & 0,11 \\
\hline Art. 141a §1 (z asystą) & 669 & 893 & 7 & 1,05 \\
\hline Art. 165 § 2 & & & & \\
\hline
\end{tabular}

Źródto: dane CZSW, obliczenia wtasne

$\mathrm{Z}$ danych wynika, że oceny funkcjonariuszy są trafne, bowiem liczba tzw. „niepowrotów" skazanych korzystających z zezwoleń na opuszczenie zakładu karnego nie przekracza $1 \%$ przy znacznej liczbie skazanych korzystających z tych zezwoleń.

Rekapitulując dotychczasowe rozważania, należy stwierdzić, iż ucieczki osadzonych z jednostek penitencjarnych nie są istotnym zagrożeniem dla bezpieczeństwa obywateli. Nie można jednak zapominać, w jakich warunkach Służba Więzienna realizuje zadanie ochrony społeczeństwa przed przestępczością. W 2008 roku w jednostkach penitencjarnych pracowało 28616 funkcjonariuszy, a osadzonych było 85152 osoby $^{15}$. Po względem liczby pracowników więziennych Polska plasuje się na 5 miejscu wśród państw europejskich. Należy jednak zauważyć, że wskaźnik obciążenia, oznaczający liczbę uwięzionych przypadających na jednego pracownika, wynosi 3,6, a więc mamy najwyższe obciążenie w państwach europejskich $^{16}$. Najlepsze warunki pracy ma personel zakładów karnych na wyspach brytyjskich (poza Szkocją 1,9) oraz we Włoszech i w Danii. Na jednego pracownika w tych państwach przypada jeden uwięziony.

Systematyczny wzrost liczby osadzonych w jednostkach penitencjarnych, którego konsekwencją są przeludnione cele, ma istotny wpływ na właściwe przeprowadzenie kontroli, co może powodować przeoczenie przygotowań do ucieczki. Świadczą o tym wskazane na wstępie przypadki budowy tuneli przez skazanych, których drążenie, mimo kontroli cel, nie zostało wykryte.

15 Stan na dzień 31.12.2008. Dane CZSW.

16 Zob. A. Siemaszko, B. Gruszczyńska, M. Marczewski, Atlas przestępczości w Polsce 4, Warszawa 2009, s. 227229. 


\section{SUMmarY}

Penitentiary facilities are places of confinement for offenders who have committed crimes of significant or high social danger and whom the court decided to isolate from the society for a certain period of time. One of the objectives of the penalty of imprisonment, under the Executive Penal Code (Art. 73), is to protect the society from criminals.

Men are created to be free. Imprisonment is a painful and unnatural condition and prisoners have a strong desire to regain their freedom as soon as possible. Thus, since the first prison was built, prisoners have done all they could to set themselves free. Is putting convicts in prison a good way to guarantee the security of the society and the lack of its exposure to the crimes they may continue to commit?

As no two convicts are the same and the extent of their demoralization and the danger to the society they pose varies, the legislator has found it to be reasonable to establish different penitentiary facilities for their confinement so as to properly distribute the convicts and minimize the danger to the society. An analysis of the relevant legal solutions and the data concerning illegal escapes from penitentiary facilities leads to the conclusion that one of the objectives of the penalty of imprisonment, namely protection of the society from criminals, is being achieved properly. 